\title{
A three-year Herpetofauna survey from one of the largest remnants of the Atlantic Rainforest Biome (Reserva Natural Vale)
}

\author{
Juliane Pereira-Ribeiro ${ }^{1,2}$; Átilla Colombo Ferreguetti ${ }^{1,3}$; Helena Godoy Bergallo ${ }^{1,4}$ \& Carlos Frederico Duarte Rocha ${ }^{1,5}$ \\ 1 Universidade do Estado do Rio de Janeiro (UERJ), Instituto de Biologia Roberto Alcântara Gomes (IBRAG), Departamento de Ecologia (DECOL). \\ Rio de Janeiro, RJ, Brasil. \\ 2 ORCID: https://orcid.org/0000-0002-0762-337X. E-mail: julianeribeiro25@gmail.com (corresponding author) \\ ${ }^{3}$ ORCID: https://orcid.org/0000-0002-5139-8835. E-mail: atilla.ferreguetti@gmail.com \\ ${ }^{4}$ ORCID: https://orcid.org/0000-0001-9771-965X. E-mail: nena.bergallo@gmail.com \\ ${ }^{5}$ ORCID: https://orcid.org/0000-0003-3000-1242. E-mail: cfdrocha@gmail.com
}

\begin{abstract}
Here we present a three-year survey of amphibian and reptile species registered in the Vale Natural Reserve (VNR), located in the north of Espírito Santo, southeastern Brazil. The VNR, along with the Sooretama Biological Reserve (SBR) and other surrounding areas, form a forest block that constitutes one of the largest remnants of continuous forest in the Atlantic Forest biome. We systematically sampled the herpetofauna community from 2015 to 2018, using the method of active search method in 27 plots of RAPELD distributed in the different types of vegetation present in the area. We recorded 39 species of amphibians belonging to the order Anura, distributed in seven families and 40 species of reptiles belonging to 20 families distributed in three orders: Crocodylia, Testudines and Squamata. The supplementation the samplings with those records from occasional encounters was important for the survey of the region's herpetofauna, mainly for reptiles. We added four species (two lizards, one amphisbaenid and one snake) to the known list for the VNR-SBR forest block: Micrablepharus maximiliani, Strobilurus torquatus, Amphisbaena alba and Tantilla sp. We demonstrated that VNR contains a high species richness of amphibians and reptiles, with a high number of anurans being endemic to the Atlantic Forest biome. The present species inventory provided the most current approximation of known the richness and composition of species of the existing herpetofauna at Vale Natural Reserve, since the period of the gathering of records is quite recent (2015-2018). Also, it brings the knowledge of some community parameters as species richness and composition not only for the whole area of the Vale Natural Reserve, but also for its different vegetation types, with no inclusion of environments outside this reserve. Furthermore, the presence of threatened species, the addition of four species to the current list, and the potential for new species to occur, reinforce the role of VNR as an important area for the protection of amphibian and reptile biodiversity in the Atlantic Forest.
\end{abstract}

Keywords. Frogs; Diversity; Reptiles; Richness; Squamata.

\section{INTRODUCTION}

The Atlantic Forest is recognized worldwide as a hotspot for biodiversity conservation (Myers et al., 2000). However, the history of the dynamics of land occupation and exploitation of natural resources has resulted in intense fragmentation of the original landscape, making this biome highly threatened (Ribeiro et al., 2009; Colombo \& Joly, 2010). Currently, only $28 \%$ of the native vegetation cover remains for the Atlantic Forest biome, with only $30 \%$ of them located in protected areas (Rezende et al., 2018). Most forest fragments have less than 100 hectares and it is estimated that only 77 forest remnants have more than 10,000 hectares (Ribeiro et al., 2009). The Vale Natural Reserve (VNR), located in Espírito Santo state in
Southeastern Brazil, together with the Sooretama Biological Reserve (SBR) and some other smaller areas in their surrounding areas, form a forest block of about 50,000 hectares, constituting one of the largest remnants of continuous forest in the Atlantic Forest biome (Kierulff et al., 2014). The VNR-SBR forest block has a remarkable richness of flora and fauna, harboring several species threatened, and its importance for the protection of the biodiversity of the Atlantic Forest has already been reinforced in several studies (see Rolim et al., 2016; Fraga et al., 2019). However, less attention has been paid to the herpetofauna community, although the number of studies has steadily increased in recent years (e.g., Pereira-Ribeiro et al., 2019; 2020a, b). The herpetofauna knowledge scenario is even worse when we consider only 
the reptile group, with only two studies available covering this region's reptile community (Rocha, 1998; Bérnils et al., 2014). A few other studies focused on ecological aspects of only one or two species (e.g., Bergallo \& Rocha, 1994; Gandolfi \& Rocha, 1998; Giaretta, 1996; Chiarello et al., 2010; Ferreguetti et al., 2018; Pereira-Ribeiro et al., 2020c).

The scarcity of information on the parameters of the local community makes it difficult to propose effective actions and measures for the protection of most species and the compilation of reliable data on the composition of local existing species is essential for the conservation of a given region (Rocha et al., 2004). In this study, we provide data on the species richness and composition of amphibians and reptiles, based on primary data resulting from a three-year monitoring effort (2015-2018) in the Vale Natural Reserve, Espírito Santo, southeastern Brazil.

\section{MATERIAL AND METHODS}

\section{Study area}

We conducted the study in the Vale Natural Reserve (19 $06^{\prime} 45^{\prime \prime} \mathrm{S}, 40^{\circ} 03^{\prime} 03^{\prime \prime} \mathrm{W}$ - centroid coordinates), a private protected area located in the municipality of Linhares, northern state of Espírito Santo, southeastern Brazil (Fig. 1).

The reserve has about 23,500 ha, with an average altitude of 46 meters and has a hot and humid tropical climate, with an average annual temperature of $23.3^{\circ} \mathrm{C}$ and annual precipitation of 1,202 mm (Kierulff et al., 2014). The region has a marked seasonality in the rainfall regime throughout the year, with the rainy season occurring from October to March and a dry season from April to September (Garay \& Rizzini, 2004).

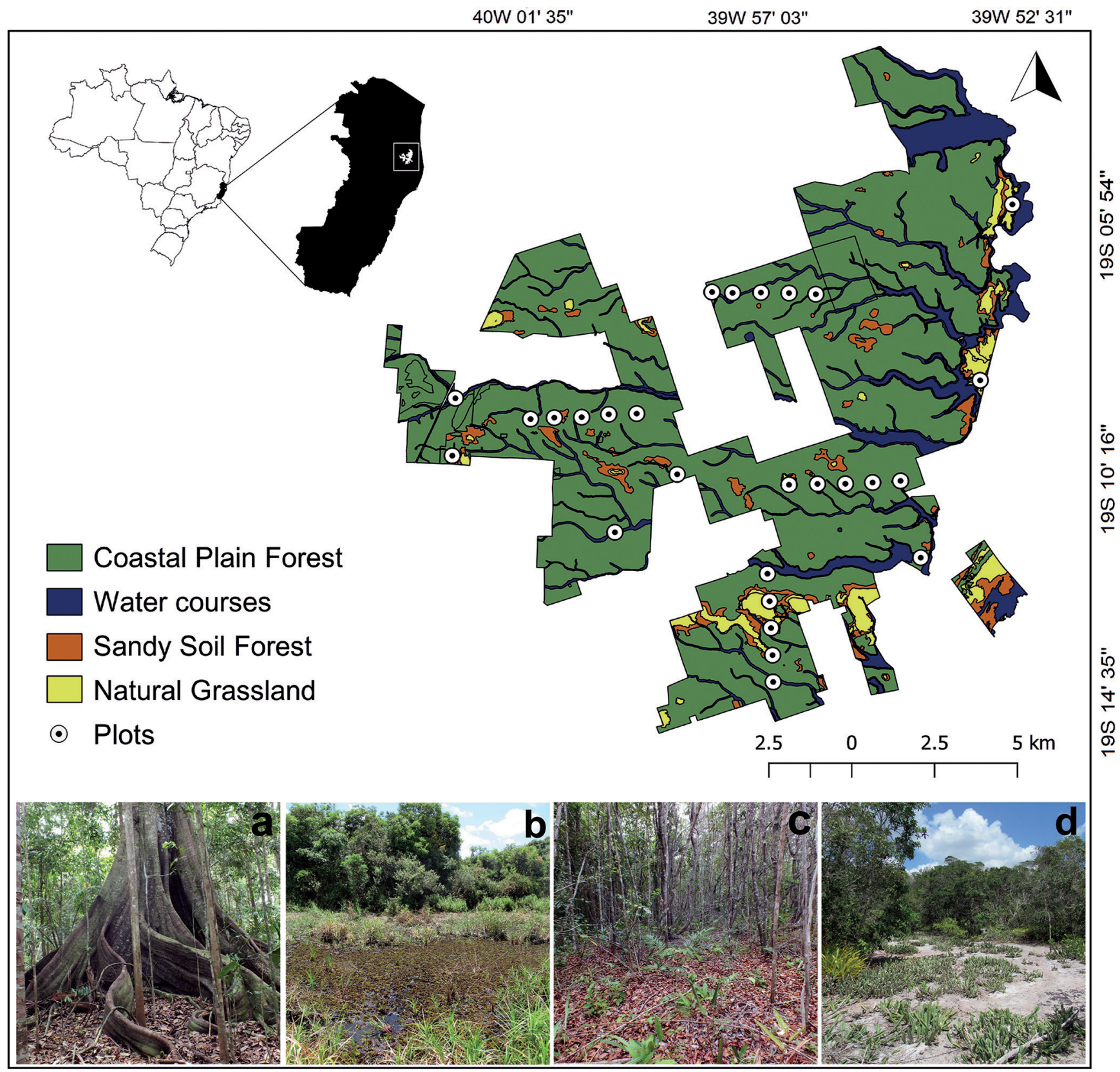

Figure 1. Location of the Vale Natural Reserve, municipality of Linhares, Espírito Santo, southeastern Brazil, showing the location of the plots and the vegetation types present in the reserve: (a) Coastal plain forest, (b) Permanent swamp, (c) Sandy soil forest, (d) Natural grassland. 
The vegetation cover of the reserve includes the Coastal Plain Forest (called "Floresta de Tabuleiro"), which can be divided into four distinct vegetation types: (1) Coastal plain forest (70\% of the area), which has a high density of large trees (up to $40 \mathrm{~m}$ in height) and dense litter; (2) Sandy soil forest (8\%), which follows strands of sandy soils and has medium-sized trees and shrubs that allow a higher incidence of sunlight on the soil; (3) natural grasslands (6\%), open areas that appear as enclaves in the forest, with floristics very similar to restingas, having herbaceous or shrub-tree vegetation and with the presence of bromeliads; and (4) Permanently or seasonally flooded forest (11\%), which is associated with water bodies and which includes swamp areas, lowland forest and riparian forest (for more details, see Peixoto et al., 2008). The remaining $6 \%$ is composed of administrative structures of the reserve.

\section{Surveys}

We carried out field sampling from June 2015 to February 2018, in the daytime period (7:00 am - 5:00 pm) and at night (6:00 pm-11:00 pm), covering the months of the dry season and the rainy season in the studied area. The field campaigns lasted from seven to 10 days and were monthly in the first year (June 2015 to May 2016) and bimonthly in the remaining period, totaling 23 field campaigns.

We used 27 plots of $250 \mathrm{~m}$ in length (totaling $10 \mathrm{~m}$ of sampled strip), following the RAPELD protocol (Magnusson et al., 2005), proportionally distributed in all vegetation types present in the area. This method consists of permanent plots, made considering the level contours of the terrain, at least $1 \mathrm{~km}$ apart and is suitable for long-term ecological surveys, as well as allowing quick samples (see Magnusson et al., 2005).

We sampled the amphibian and reptile species along the plots using the active search method, with visual and acoustic samplings (Crump \& Scott-Jr., 1994). The plots were sampled using the same protocol, by two observers, spending an approximate time of $1 \mathrm{~h}$ along with each plot. In each plot, we search for individuals in the available microhabitats, such as litter, hollows in trees, shrubs, fallen trunks, among others. We recorded all individuals of herpetofauna species located in a range of $5 \mathrm{~m}$ on each side of the plotline. Considering the entire study period, we sampled each plot seven times in each period (day and night). Additionally, we recorded those individuals from herpetofauna species occasionally found on the trails and roads of the Vale Natural Reserve.

We photographed and identified all the individuals captured and later released them in the same place where they were originally found. We identified the species based on the specific literature of each group and with the help of guides of amphibians and reptiles from the Atlantic Forest (e.g., Gasparini 2012; Haddad et al., 2013; Marques et al., 2019). Additionally, whenever necessary, we seek confirmation from specialists. When possible, an individual per species was collected as a vouch- er (License Sisbio/RAN № 46327-4), especially individuals of species that had not yet been registered for the area.

We identified some individuals based on the characteristics of the species, through photography, when it was not possible to perform the collection. The collected individuals were killed with anesthetic xylocaine and fixed in $10 \%$ formalin solution, following standardized procedures. We deposited the specimens in the herpetological collection of the Museu Nacional, Rio de Janeiro (MNRJ) (Appendix).

\section{Data analysis}

To estimate species richness for the area, we used species presence/absence data to perform a species rarefaction curve, using the Chao 2 estimator (Magurran, 2013), with 1,000 randomizations in the model. We used this estimator due to the high number of species that were recorded only once. For this analysis, we used the software EstimateS 9.0 (Colwell, 2013). The taxonomy adopted follows Frost (2019) for amphibians and Costa \& Bérnils (2018) for reptiles. To verify if the species were endemic to the Atlantic Forest, we used Monteiro-Filho \& Conte (2017) and Costa \& Bérnils (2018).

\section{RESULTS}

\section{Amphibians}

During the study period, we recorded 39 species of amphibians, all belonging to the order Anura, distributed in seven families (Table 1, Figs. 2 and 3). The Hylidae family was the most speciose (21 spp., 54\%), followed by Leptodactylidae (8 spp., 20\%) and Microhylidae (4 spp., $10 \%)$.

We recorded most species (31 species, 80\%) using the active search method in the plots, with 14 of the species being recorded exclusively by this method (Table 1). The accumulation curve for anurans reached an asymptote (Fig. 4), with an estimated richness of 39.72 \pm 1.37 (Chao 2).

Of the anuran species recorded, approximately $75 \%$ are endemic to the Atlantic Forest biome. None of the registered anuran species is included in the IUCN (IUCN 2020), Brazil (ICMBIO/MMA, 2018) or the state of Espírito Santo (Fraga et al., 2019) red lists of endangered species.

\section{Reptiles}

We recorded 40 species of reptiles belonging to 20 families distributed in three orders: Crocodylia, Testudines and Squamata (Table 2, Figs. 5 and 6). Crocodylia was represented by only one species in the Alligatoridae family (Caiman latirostris). Testudines was represented by four species, belonging to the families Chelidae (1), Testudinidae (2) and Geoemydidae (1). Squamata was represented by 35 species, being 17 species of lizards, one amphisbaenid and 17 species of snakes (Table 2). 
Table 1. List of amphibian species recorded in the Vale Natural Reserve, municipality of Linhares, Espírito Santo, southeastern Brazil. $A S=A c t i v e ~ s e a r c h, ~ O E=$ occasional encounter, END/AF = Endemic to the Brazilian Atlantic Forest. For Conservation Status, DD = Data Deficient, $\mathrm{LC}=$ Least Concern, with sources indicated in parentheses (IUCN $=$ International Union for Conservation of Nature).

\begin{tabular}{|c|c|c|c|}
\hline Order/Family/Species & Method & END/AF & $\begin{array}{c}\text { Conservation } \\
\text { status } \\
\end{array}$ \\
\hline \multicolumn{4}{|l|}{ ANURA } \\
\hline \multicolumn{4}{|l|}{ Bufonidae } \\
\hline Rhinella crucifer (Wied-Neuwied, 1821) & $\mathrm{AS} / 0 \mathrm{E}$ & $x$ & LC (IUCN) \\
\hline Rhinella granulosa (Spix, 1824) & $0 \mathrm{E}$ & - & LC (IUCN) \\
\hline Rhinella diptycha (Cope, 1862) & $\mathrm{OE}$ & - & LC (IUCN) \\
\hline \multicolumn{4}{|l|}{ Craugastoridae } \\
\hline Haddadus binotatus (Spix, 1824) & $\mathrm{AS} / 0 \mathrm{E}$ & $x$ & LC (IUCN) \\
\hline \multicolumn{4}{|l|}{ Hylidae } \\
\hline Aparasphenodon brunoi Miranda-Ribeiro, 1920 & $\mathrm{AS} / 0 \mathrm{E}$ & $x$ & LC (IUCN) \\
\hline Boana faber (Wied-Neuwied, 1821) & $\mathrm{AS} / 0 \mathrm{E}$ & - & LC (IUCN) \\
\hline Boana pombali (Caramaschi, Pimenta, and Feio, 2004) & AS & $x$ & LC (IUCN) \\
\hline Boana semilineata (Spix, 1824) & $\mathrm{AS} / 0 \mathrm{E}$ & $x$ & LC (IUCN) \\
\hline Dendropsophus anceps (Lutz, 1929) & $\mathrm{AS} / 0 \mathrm{E}$ & $x$ & LC (IUCN) \\
\hline Dendropsophus bipunctatus (Spix, 1824) & $\mathrm{AS} / 0 \mathrm{E}$ & $x$ & LC (IUCN) \\
\hline Dendropsophus branneri (Cochran, 1948) & $\mathrm{AS} / 0 \mathrm{E}$ & $x$ & LC (IUCN) \\
\hline Dendropsophus decipiens (Lutz, 1925) & $\mathrm{AS} / 0 \mathrm{E}$ & $x$ & LC (IUCN) \\
\hline Dendropsophus elegans (Wied-Neuwied, 1824) & $O E$ & $x$ & LC (IUCN) \\
\hline Dendropsophus minutus (Peters, 1872) & $\mathrm{OE}$ & - & LC (IUCN) \\
\hline Dendropsophus seniculus (Cope, 1868) & $\mathrm{OE}$ & $x$ & LC (IUCN) \\
\hline Ololygon agilis (Cruz \& Peixoto, 1983) & AS & $x$ & LC (IUCN) \\
\hline Ololygon argyreornata (Miranda-Ribeiro, 1926) & AS & $x$ & LC (IUCN) \\
\hline Phyllodytes /uteolus (Wied-Neuwied, 1824) & AS & $x$ & LC (IUCN) \\
\hline Scinax alter (Lutz, 1973) & AS & $x$ & LC (IUCN) \\
\hline Scinax cuspidatus (Lutz, 1925) & AS & $x$ & LC (IUCN) \\
\hline
\end{tabular}

The species accumulation curves did not reach an asymptote nor for snakes, nor for the combined species of local reptile fauna (Fig. 7). However, when we considered only lizards, there was a trend for the curve to stabilize. The estimated richness was approximately of 54 species of reptiles for the area $(54.35 \pm 9.58)$. The estimated richness for lizards was about 19 species $(18.91 \pm 2.78)$ and for snakes about 34 species $(33.52 \pm 8.14)$.

We recorded 23 species (57\%) using the active search method in the plots and, together with the occasional encounters we registered 32 species $(80 \%$, Table 2$)$. Of the reptile species recorded, $25 \%$ are endemic to the Atlantic Forest. The only species of the order Crocodylia registered (Caiman latirostris) is categorized as Endangered on the list of endangered animals of Espírito Santo (Fraga et al., 2019). Two species of turtles are in a threat category by the IUCN Red List of Endangered Species, with Acanthochelys radiolata being categorized as Near Threatened and Chelonoidis denticulatus categorized as Vulnerable. One species of lizard (Ameivula nativo) is categorized as Endangered in the list of endangered animals in Brazil (Colli et al., 2018) and in the state of Espírito Santo (Fraga et al., 2019).

\section{DISCUSSION}

\section{Amphibians}

We found a richness of 39 anuran species in the Vale Natural Reserve (VNR), which is equivalent to about $29 \%$

\begin{tabular}{lccc}
\hline \multicolumn{1}{c}{ Order/Family/Species } & Method & END/AF & $\begin{array}{c}\text { Conservation } \\
\text { status }\end{array}$ \\
\hline Scinax eurydice (Bokermann, 1968) & AS & $X$ & LC (IUCN) \\
Scinax fuscovarius (Lutz, 1925) & OE & - & LC (IUCN) \\
Scinax sp. & AS & $X$ & - \\
Sphaenorhynchus planicola (Lutz and Lutz, 1938) & AS & $X$ & LC (IUCN) \\
Trachycephalus mesophaeus (Hensel, 1867) & AS/OE & $X$ & LC (IUCN) \\
Leptodactylidae & & & \\
Adenomera thomei (Almeida \& Angulo, 2006) & AS & $X$ & LC (IUCN) \\
Leptodactylus fuscus (Schneider, 1799) & AS/OE & - & LC (IUCN) \\
Leptodactylus latrans (Steffen, 1815) & OE & - & LC (IUCN) \\
Leptodactylus mystacinus (Burmeister, 1861) & AS/OE & - & LC (IUCN) \\
Leptodactylus natalensis Lutz, 1930 & AS & - & LC (IUCN) \\
Physalaemus aguirrei Bokermann, 1966 & AS/OE & $X$ & LC (IUCN) \\
Physalaemus gr. signifer & AS/OE & - & - \\
Physalaemus obtectus Bokermann, 1966 & AS/OE & $X$ & DD (IUCN) \\
Microhylidae & & & \\
Chiasmocleis capixaba Cruz, Caramaschi \& lzecksohn, 1997 & AS & $X$ & LC (IUCN) \\
Chiasmocleis schubarti Bokermann, 1952 & AS & $X$ & LC (IUCN) \\
Dasypops schirchi Miranda-Ribeiro, 1924 & AS/OE & $X$ & LC (IUCN) \\
Stereocyclops incrassatus Cope, 1870 & AS/OE & $X$ & LC (IUCN) \\
Odontrophrynidae & & & \\
Proceratophrys laticeps Izecksohn \& Peixoto, 1981 & AS & $X$ & LC (IUCN) \\
Phyllomedusidae & & & \\
Phyllomedusa burmeisteri Boulenger, 1882 & AS/OE & $X$ & LC (IUCN) \\
\hline
\end{tabular}

of the amphibian species known to occur to the whole state of Espírito Santo (Almeida et al., 2011). The rarefaction curve for frogs tended to stabilize, with an expected richness of about 40 species, a value quite similar to that species richness we recorded. Although some recent studies on frog communities in this reserve had provided a considerable number of frog species varying from 21 up to 24 species (Pereira-Ribeiro et al., 2019, 2020a, b), they were designed for a shorter period and using particular sampling efforts and methods to study just one of the physiognomies of the reserve (i.e., the Coastal plain forest or Floresta de Tabuleiro) (Pereira-Ribeiro et al., 2020b), or to investigate some particular ecological parameters as the activity, occupancy, detectability and short-term rainfall effects on the frogs activity (Pereira-Ribeiro et al., 2019, 2020a, b). Conversely, the present study based on a systematic method of sampling (in RAPELD Modules) covered all types of vegetation present in the area of the reserve and sampled continuously for about three years, which allowed to reach a better approximation of the actual frog species richness occurring in the reserve. In addition, the present study took into account those individuals from species we occasionally found when moving along the reserve, which added six species to the study: Rhinella granulosa, Rhinella diptycha, Dendropsophus elegans, Dendropsophus minutus, Dendropsophus seniculus, Leptodactylus latrans. Although Almeida \& Gasparini (2014) reported a richness of 56 species of amphibians for this region, they used primary and secondary data from amphibians, and did not restrict their sampling to the species collected in the VNR (23,500 hectares). They also 
included data from the Sooretama Biological Reserve (24,000 hectares) and from surrounding environments of these reserves. Since that study did not report which species were specifically recorded in each area and took in consideration a too larger area (of at least a double size), this prevents comparisons with our results which bring data collected exclusively at VNR.

Approximately $75 \%$ of the anuran species recorded in our study are endemic to the Atlantic Forest, following the same trend of rate of endemism in studies on anurans in this biome (e.g., 77.2\% - Dias et al., 2014; 70\% - Campos \& Lourenço-de-Moraes, 2017). The Atlantic Forest biome contains the highest degree of endemism of anuran amphibians in Brazil (about $80 \%$ of the species known in this biome are endemic), mainly because it has highly heterogeneous environments throughout the domain (e.g., different plant formations, latitudes and altitudes, Rossa-Feres et al., 2017). The Vale Natural Reserve has a mosaic with different vegetation types and availability of microenvironments, which allow the

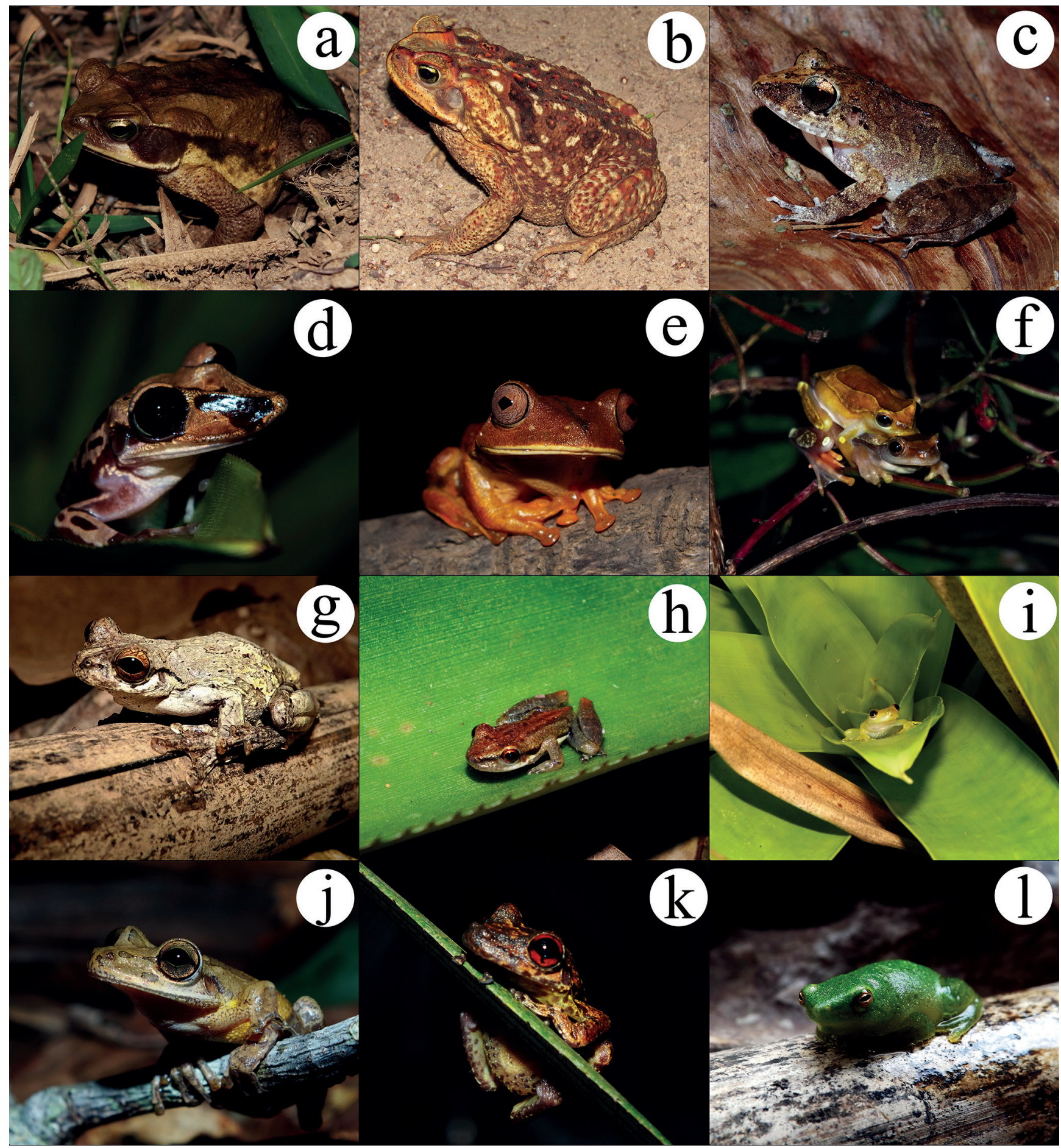

Figure 2. Some of the anuran species we recorded in the Vale Natural Reserve, municipality of Linhares, Espírito Santo, southeastern Brazil: (a) Rhinella crucifer, (b) Rhinella diptycha, (c) Haddadus binotatus, (d) Aparasphenodon brunoi, (e) Boana semilineata, (f) Dendropsophus elegans, (g) Dendropsophus seniculus, (h) Ololygon agilis, (i) Phyllodytes luteolus, (j) Scinax eurydice, (k) Scinax sp., (I) Sphaenorhynchus planicola. 
occurrence of species with different habits requirements. Pereira-Ribeiro et al. (2020a) demonstrated that the VNR frog community varied between vegetation types, with some species being exclusively found in each phytophysiognomy, and emphasizing the importance of the structural factors along landscape affecting the diversity of species. One of the criteria for identifying priority conservation areas and assessing the conservation value of ecoregions is the presence of endemic species (Loyola et al., 2007). Thus, considering the high endemism of anurans presented here, our results underscore the importance of VNR for the conservation of this group in the Atlantic Forest.

\section{Reptiles}

The records we obtained for the VNR reptile fauna currently indicate the occurrence of 40 species, being a crocodilian, four turtles, 17 lizards, one amphisbaenid and 17 snakes. Our result is similar to that found by Rocha (1998), who registered 38 species of reptiles in the same study area ( 2 turtles, 16 lizards, 2 amphisbaenids and 18 snakes). The study of Bérnils et al. (2014) indicated a richness of 64 species, being one crocodilian, four turtles, two amphisbenids, 18 lizards and 39 snakes for the whole piece of remnants of VNR plus Sooretama Biological Reserve and surrounding environments. However, as

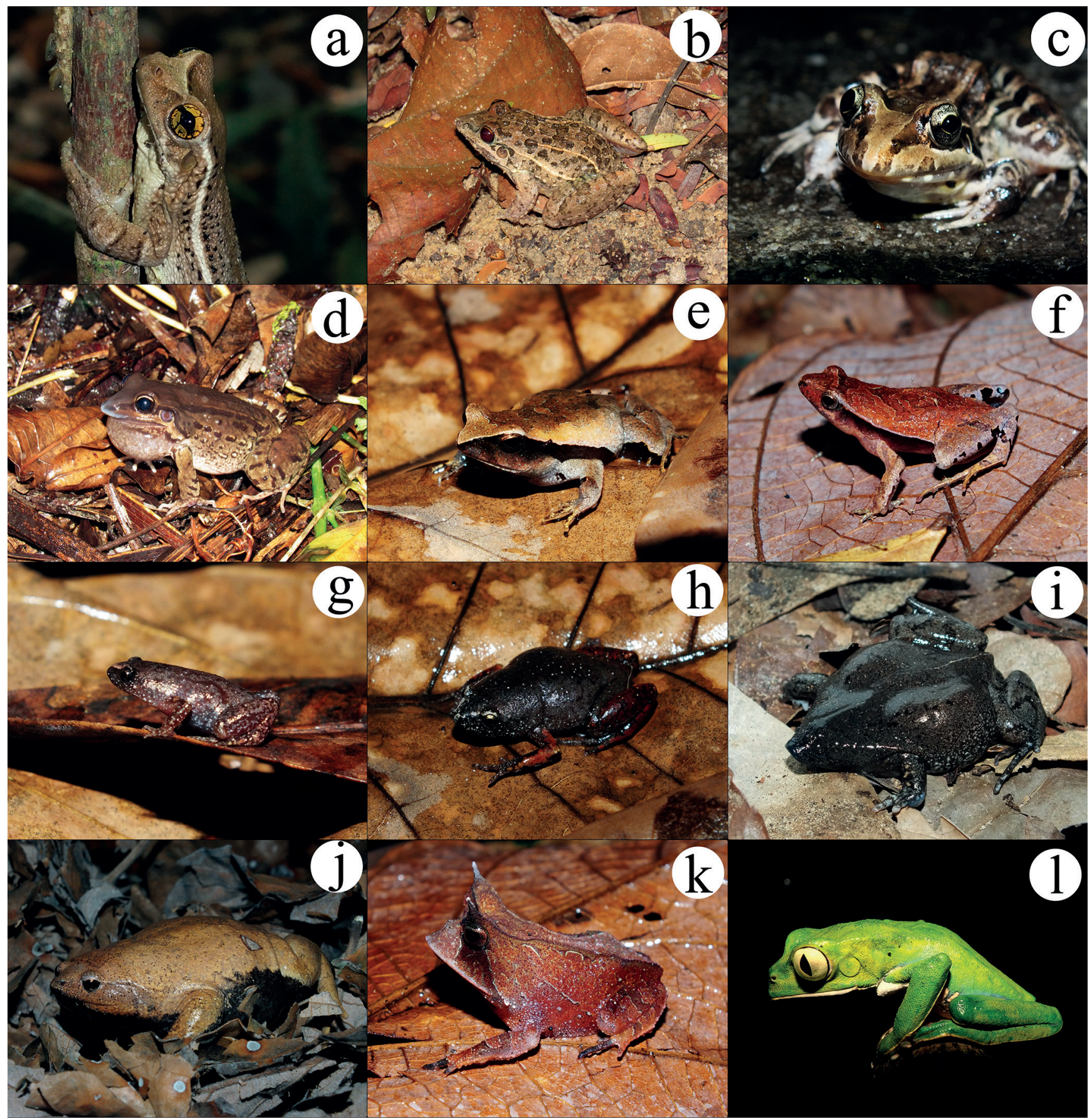

Figure 3. Some of the anuran species we recorded in the Vale Natural Reserve, municipality of Linhares, Espírito Santo, southeastern Brazil: (a) Trachycephalus mesophaeus, (b) Leptodactylus fuscus, (c) Leptodactylus latrans, (d) Leptodactylus mystacinus, (e) Physalaemus aguirrei, (f) Physalaemus gr. signifer, (g) Chiasmocleis capixaba, (h) Chiasmocleis schubarti, (i) Dasypops schirchi, (j) Stereocyclops incrassatus, (k) Proceratophrys laticeps, (I) Phyllomedusa burmeisteri. 
Table 2. List of reptile species recorded in the Vale Natural Reserve, municipality of Linhares, Espírito Santo, southeastern Brazil. $A S=A c t i v e ~ s e a r c h, ~ 0 E=0 c c a-$ sional encounter, END/AF = Endemic to the Brazilian Atlantic Forest. For Conservation Status, DD $=$ Data Deficient, NT $=$ Near Threatened, $\mathrm{LC}=\mathrm{Least}$ Concern, $\mathrm{EN}=$ Endangered, $\mathrm{VU}=$ Vulnerable, with sources indicated in parentheses $(\mathrm{ES}=$ List of endangered species of the State of Espírito Santo, BRA $=$ List of endangered species of the Brazil, IUCN = International Union for Conservation of Nature).

\begin{tabular}{|c|c|c|c|}
\hline Order/Family/Species & Method & END/AF & $\begin{array}{c}\text { Conservation } \\
\text { status } \\
\end{array}$ \\
\hline \multicolumn{4}{|l|}{ CROCODYLIA } \\
\hline \multicolumn{4}{|l|}{ Alligatoridae } \\
\hline Caiman latirostris (Mikan, 1820) & $\mathrm{AS} / 0 \mathrm{E}$ & - & $\begin{array}{l}\text { LC (IUCN), EN } \\
(\text { ES) }\end{array}$ \\
\hline \multicolumn{4}{|l|}{ TESTUDINES } \\
\hline \multicolumn{4}{|l|}{ Chelidae } \\
\hline Acanthochelys radiolata (Mikan, 1820) & $\mathrm{OE}$ & $x$ & $\begin{array}{c}\text { NT (IUCN), LC } \\
\text { (BRA) }\end{array}$ \\
\hline \multicolumn{4}{|l|}{ Testudinidae } \\
\hline Chelonoidis carbonarius (Spix, 1824) & $\mathrm{AS} / 0 \mathrm{E}$ & - & $\mathrm{DD}(\mathrm{ES})$ \\
\hline Chelonoidis denticulatus (Linnaeus, 1766) & $\mathrm{AS} / 0 \mathrm{E}$ & - & $\begin{array}{l}\text { VU (IUCN), LC } \\
\text { (BRA), DD (ES) }\end{array}$ \\
\hline \multicolumn{4}{|l|}{ Geoemydidae } \\
\hline Rhinoclemmys punctularia (Daudin, 1801) & $\mathrm{OE}$ & - & - \\
\hline \multicolumn{4}{|l|}{ SQUAMATA } \\
\hline \multicolumn{4}{|l|}{ Gekkonidae } \\
\hline Hemidactylus mabouia (Moreau Jonnès, 1818) & $\mathrm{OE}$ & - & - \\
\hline \multicolumn{4}{|l|}{ Phyllodactylidae } \\
\hline Gymnodactylus darwinii (Gray, 1845) & $\mathrm{AS} / 0 \mathrm{E}$ & $x$ & LC (IUCN) \\
\hline \multicolumn{4}{|l|}{ Mabuyidae } \\
\hline Brasiliscincus agilis (Raddi, 1823) & $\mathrm{AS} / 0 \mathrm{E}$ & $x$ & LC (IUCN) \\
\hline Psychosaura macrorhyncha (Hoge, 1947) & $\mathrm{AS} / 0 \mathrm{E}$ & $x$ & LC (IUCN) \\
\hline \multicolumn{4}{|l|}{ Dactyloidae } \\
\hline Dactyloa punctata (Daudin, 1802) & $\mathrm{AS} / 0 \mathrm{E}$ & - & - \\
\hline Norops ortonii (Cope, 1868) & $\mathrm{OE}$ & - & - \\
\hline \multicolumn{4}{|l|}{ Polychrotidae } \\
\hline Polychrus marmoratus (Linnaeus, 1758) & $\mathrm{OE}$ & - & LC (IUCN) \\
\hline \multicolumn{4}{|l|}{ Tropiduridae } \\
\hline Strobilurus torquatus Wiegmann, 1834 & AS & $x$ & LC (IUCN) \\
\hline Tropidurus torquatus (Wied, 1820) & $\mathrm{AS} / 0 \mathrm{E}$ & - & LC (IUCN) \\
\hline \multicolumn{4}{|l|}{ Anguidae } \\
\hline Diploglossus fasciatus (Gray, 1831) & $\mathrm{OE}$ & - & LC (IUCN) \\
\hline \multicolumn{4}{|l|}{ Gymnophthalmidae } \\
\hline Micrablepharus maximiliani (Reinhardt e Luetken, 1862) & AS & - & LC (IUCN) \\
\hline
\end{tabular}

we have pointed above, such comparisons are not feasible due to considerable differences among the study of Bérnils et al. (2014) and the present study, in terms of the differences in the size of the general geographic area considered, methodologies and field efforts employed. However, even considering the larger sampled area in the study by Bérnils et al. (2014), our results added four species to the known reptile list for the VNR-SBR forest block: Micrablepharus maximiliani, Strobilurus torquatus, Amphisbaena alba and Tantilla sp.

Our estimates regarding reptile richness suggests that there is potential to still register some additional species of reptiles in the area, especially snakes. We believe that the use of additional sampling methods in future studies, such as pitfalls and funnels, can improve registering of additional species. It is known that the use of combined different sampling methods tends to increase the effectiveness of species richness estimates and increase the chance of capturing species with different ecological requirements (Hutchens \& DePerno, 2009), reinforcing

\begin{tabular}{|c|c|c|c|}
\hline Order/Family/Species & Method & END/AF & $\begin{array}{c}\text { Conservation } \\
\text { status }\end{array}$ \\
\hline Ecpleopus gaudichaudii Duméril e Bibron, 1839 & AS & $x$ & LC (IUCN) \\
\hline Leposoma scincoides Spix, 1825 & AS/OE & $x$ & LC (IUCN) \\
\hline \multicolumn{4}{|l|}{ Teiidae } \\
\hline Ameiva ameiva (Linnaeus, 1758) & $\mathrm{AS} / 0 \mathrm{E}$ & - & LC (IUCN) \\
\hline Ameivula nativo (Rocha, Bergallo \& Peccinini-Seale, 1997) & $\mathrm{AS} / 0 \mathrm{E}$ & $x$ & EN (BRA, ES) \\
\hline Kentropyx calcarata Spix, 1825 & $\mathrm{AS} / 0 \mathrm{E}$ & - & LC (IUCN) \\
\hline Salvator merianae Duméril \& Bibron, 1839 & $\mathrm{AS} / 0 \mathrm{E}$ & - & LC (IUCN) \\
\hline \multicolumn{4}{|l|}{ Amphisbaenidae } \\
\hline Amphisbaena alba Linnaeus, 1758 & $\mathrm{OE}$ & - & LC (IUCN) \\
\hline \multicolumn{4}{|l|}{ Typhlopidae } \\
\hline Amerotyphlops brongersmianus (Vanzolini, 1976) & AS & - & LC (IUCN) \\
\hline \multicolumn{4}{|l|}{ Boidae } \\
\hline Corallus hortulanus (Linnaeus, 1758) & $\mathrm{OE}$ & - & LC (IUCN) \\
\hline Epicrates cenchria (Linnaeus, 1758) & $\mathrm{OE}$ & - & - \\
\hline \multicolumn{4}{|l|}{ Colubridae } \\
\hline Chironius foveatus Bailey, 1955 & $\mathrm{OE}$ & $x$ & LC (IUCN) \\
\hline Chironius fuscus (Linnaeus, 1758) & $\mathrm{AS} / 0 \mathrm{E}$ & - & LC (IUCN) \\
\hline Drymoluber dichrous (Peters, 1863) & OE & - & LC (IUCN) \\
\hline Leptophis ahaetulla (Linnaeus, 1758) & $\mathrm{OE}$ & - & LC (IUCN) \\
\hline Oxybelis aeneus (Wagler, 1824) & AS & - & LC (IUCN) \\
\hline Spilotes sulphureus (Wagler, 1824) & $\mathrm{AS} / 0 \mathrm{E}$ & - & LC (IUCN) \\
\hline Tantilla sp. & $\mathrm{OE}$ & - & - \\
\hline \multicolumn{4}{|l|}{ Dipsadidae } \\
\hline Erythrolamprus miliaris (Linnaeus, 1758) & $\mathrm{OE}$ & - & LC (IUCN) \\
\hline Leptodeira annulata (Linnaeus, 1758) & AS & - & LC (IUCN) \\
\hline Oxyrhopus rhombifer Duméril, Bibron \& Duméril, 1854 & AS & - & LC (IUCN) \\
\hline Siphlophis compressus (Daudin, 1803) & $\mathrm{OE}$ & - & LC (IUCN) \\
\hline Thamnodynastes hypoconia (Cope, 1860) & AS & - & LC (IUCN) \\
\hline \multicolumn{4}{|l|}{ Elapidae } \\
\hline Micrurus corallinus (Merrem, 1820) & $\mathrm{AS} / 0 \mathrm{E}$ & $x$ & LC (IUCN) \\
\hline \multicolumn{4}{|l|}{ Viperidae } \\
\hline Bothrops jararaca (Wied-Neuwied, 1824) & $\mathrm{OE}$ & - & LC (IUCN) \\
\hline
\end{tabular}

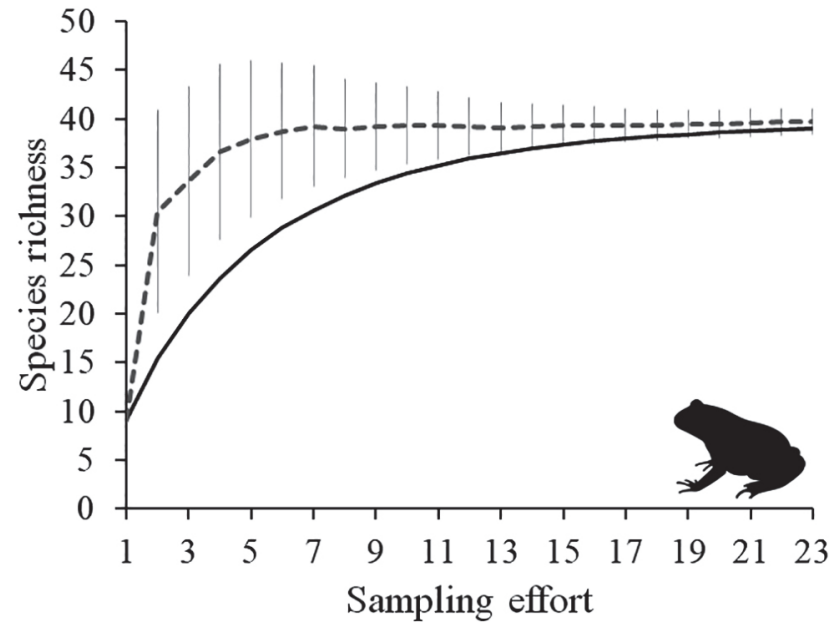

Figure 4. Accumulation (black line) and rarefaction curves (gray line) of the amphibian species recorded during the 23 sampling campaigns from 2015 to 2018 in the Vale Natural Reserve, municipality of Linhares, Espírito Santo, southeastern Brazil. 
the importance of combining more than one sampling method for reptiles for a more complete inventory. Also, while we recorded eight species exclusively by the active search method, we recorded 16 species exclusively by occasional encounters which points out for the importance of the inclusion of such unexpected encounters to improve substantially species richness and composition during inventories.
The only exotic species recorded at RNV was the gekkonid lizard Hemidactylus mabouia, a species considered invasive in Brazil (Rocha et al., 2011). This species is commonly associated with anthropic or perianthropic environments and, its invasion in natural areas in Brazil is increasing steadily, especially in open habitats (Rocha et al., 2011; Oliveira et al., 2016). In natural environments, H. mabouia can interact with native species in the com-

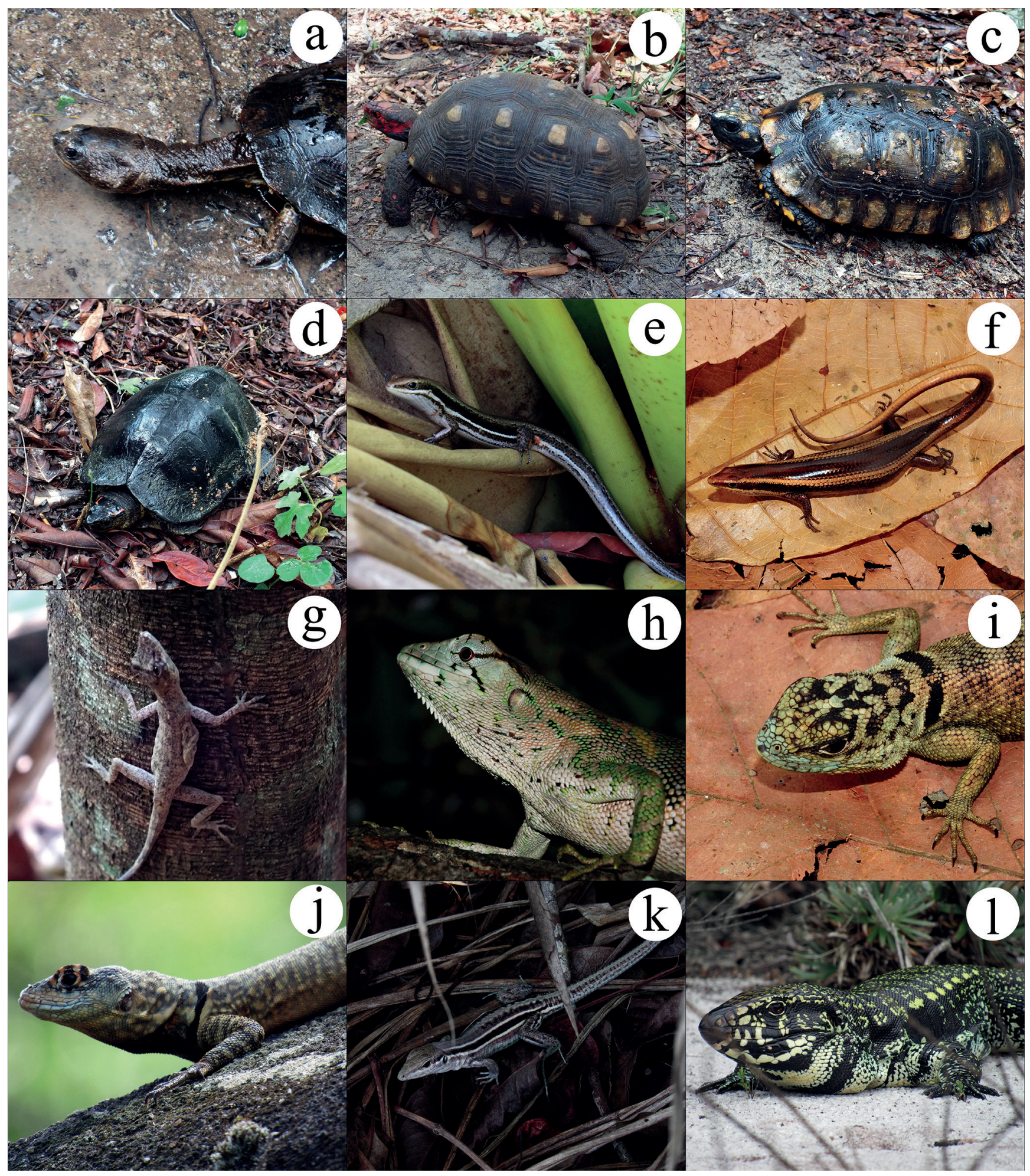

Figure 5. Some of the reptile species we recorded in the Vale Natural Reserve, municipality of Linhares, Espírito Santo, southeastern Brazil: (a) Acanthochelys radiolata, (b) Chelonoidis carbonaria, (c) Chelonoidis denticulatus, (d) Rhinoclemmys punctularia, (e) Brasiliscincus agilis, (f) Psychosaura macrorhyncha, (g) Norops ortonii, (h) Polychrus marmoratus, (i) Strobilurus torquatus, (j) Tropidurus torquatus, (k) Ameivula nativo, (I) Salvator merianae. 
munity, sharing space and food resources (Rocha et al., 2011). In addition, $H$. mabouia can also be an occasional prey for native snake and lizard species (Rocha \& Vrcibradic, 1998; Rocha et al., 2011). However, more studies are needed to more accurately assess the potential positive and negative effects imposed on sympatric species (Rocha et al., 2011). The individuals of this species we registered in the reserve were found only near to the ad- ministrative headquarters of the Reserve, in perianthropic areas and thus, not in natural environments. Although it can suggest that invasion of natural habitats by this exotic and invasive gecko still not occurred at VNR. Data from 1998 (Rocha, 1998) points the occurrence of this species in the natural grassland physiognomy, an open habitat know to favor invasion by this species (Rocha et al., 2011). Therefore, we recommend monitoring of this

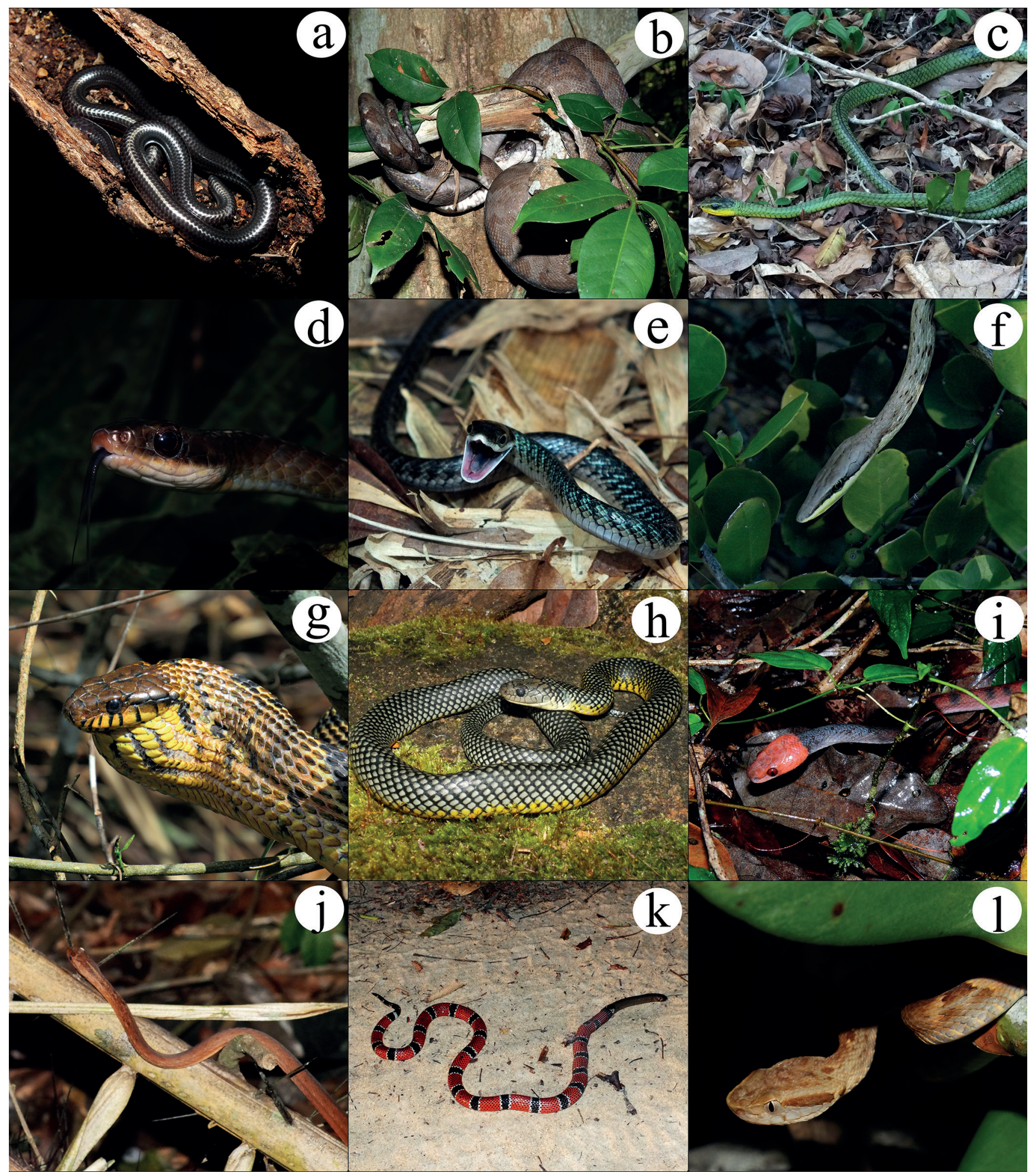

Figure 6. Some of the reptile species we recorded in the Vale Natural Reserve, municipality of Linhares, Espírito Santo, southeastern Brazil: (a) Amerotyphlops brongersmianus, (b) Corallus hortulanus, (c) Chironius foveatus, (d) Chironius fuscus, (e) Leptophis ahaetulla, (f) Oxybelis aeneus, (g) Spilotes sulphureus, (h) Erythrolamprus miliaris, (i) Siphlophis compressus, (j) Thamnodynastes hypoconia, (k) Micrurus corallinus preying on A. brongersmianus, (l) Bothrops jararaca. 
invasive lizard in natural environments of the reserve, to access to what extent the process of invasion may have effectively occurred.

Caiman latirostris, Acanthochelys radiolata, Chelonoidis denticulatus, and Ameivula nativo were the only recorded species that are in any category of risk of extinction, depending on the global (IUCN), national (ICMBio/MMA) or regional lists (State list). Caiman latirostris is distributed in the southeastern region of South America, with more than $70 \%$ of the global distribution of the species being in the Brazilian territory (Siroski et al., 2020). This species usually occurs in lentic environments (e.g., ponds, mangroves, swamps; Moulton et al., 1999), although it can also occur in environments altered by humans, such as effluent treatment plants and water reservoirs (Scott-Jr. et al., 1990; Filogônio et al., 2010). Several factors threaten the populations of this species throughout its distribution, such as drainage of water bodies, deforestation, habitat reduction, poaching, among others (Siroski et al., 2020). In Espírito Santo, the species was categorized as Endangered due to the impact of poaching on the populations of this species in the State, although there are no studies that report the magnitude of this impact (Fraga et al., 2019). In VNR, we found individuals of C. latirostris in two permanently flooded areas. Thus, the monitoring of this species, as well as the evaluation and analysis of the magnitude of the factors that may be threats is of fundamental importance for the conservation of the populations of the species in the region.

Acanthochelys radiolata is an endemic species in Brazil and was categorized as Near threatened by IUCN in 1996 (Tortoise \& Freshwater Turtle Specialist Group, 1996a). In the Brazilian list of threatened animals, the conservation status has changed to Least concern due to new and better information available (ICMBio/MMA, 2018). The species has a wide distribution, occurring in the Cerrado and Atlantic Forest biomes, where it is associated with wetlands (Iverson, 1992). At VNR, we occasionally encounter an individual of the species, in a temporary puddle after heavy rain.

Chelonoidis denticulatus is widely distributed in Brazil mainly in the Amazon and in the Atlantic Rainforest, where the species occur as disjunct population in eastern coastal forests with occurrence also recorded to Cerrado and Pantanal (Pritchard \& Trebbau, 1984, Iverson, 1992). This tortoise is usually associated with forested habitats in humid environments (Jerozolimski et al., 2009). Currently, this tortoise keeps populations in huge rem-
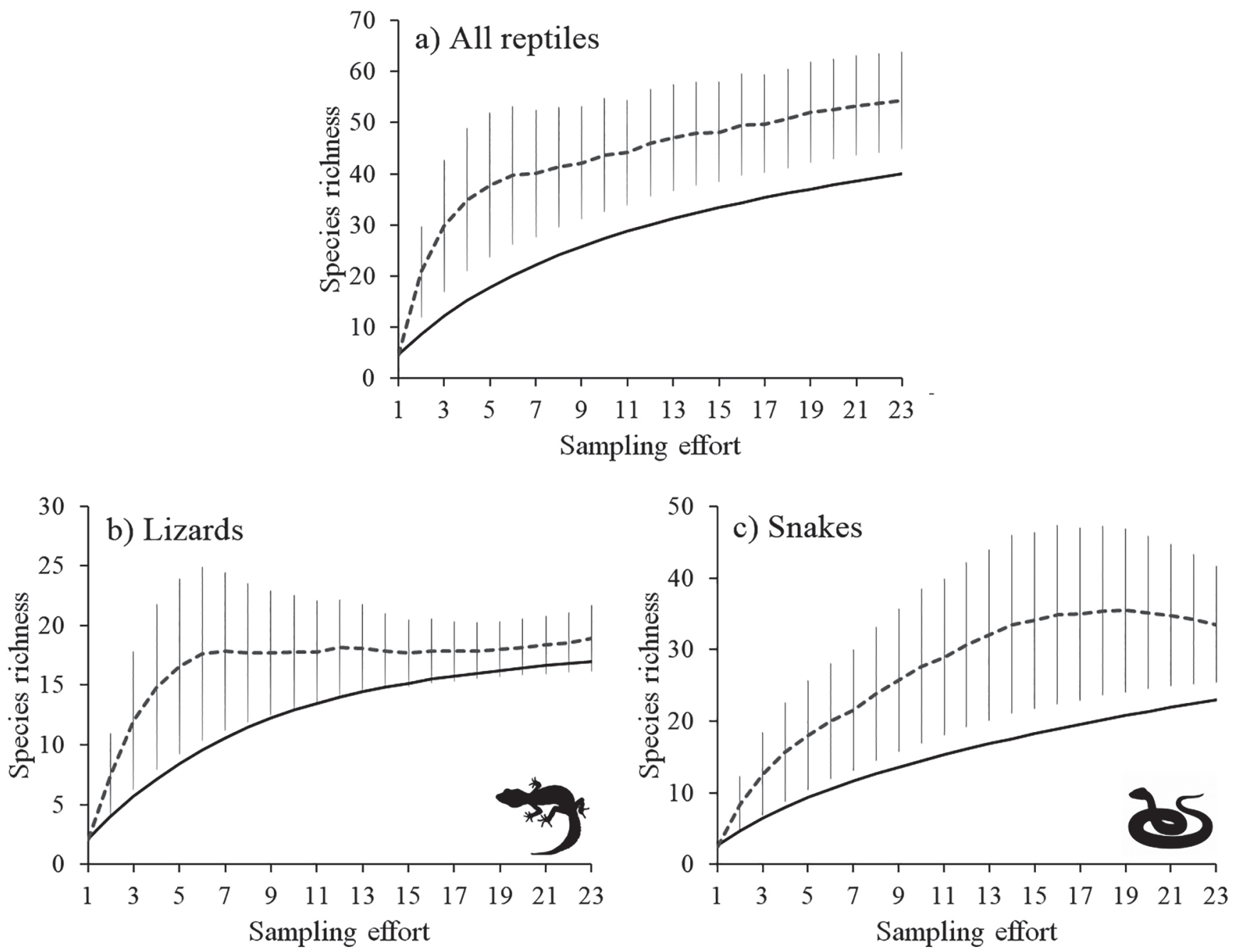

Figure 7. Accumulation (black line) and rarefaction curves (gray line) of the reptile species recorded during the 23 sampling campaigns from 2015 to 2018 in the Vale Natural Reserve, municipality of Linhares, Espírito Santo, southeastern Brazil. 
nants of the Atlantic Rainforest as VNR (Rocha, 1998; Bérnils et al., 2014) and Sooretama Biological Reserve (Merçon, 2015), being apparently not able to maintain viable populations in small fragments. Our records regarding $C$. denticulatus and its congener $C$. carbonarius during the present study at VNR are suggestive that both tortoise species are relatively abundant in this reserve. Similar to A. radiolata, C. denticulatus was categorized as Vulnerable in the IUCN list (Tortoise \& Freshwater Turtle Specialist Group 1996b), as Least Concern in the Brazilian list of endangered animals (ICMBio/MMA, 2018), but it was categorized as Data Deficient in the recent list of the threatened fauna and flora of Espírito Santo State (Fraga et al., 2019).

Ameivula nativo is a unisexual parthenogenetic lizard endemic to the coastal habitats of sand dunes (restingas and natural grasslands) of the Atlantic Forest biome, occurring only along the east coast of Brazil, in the states of Bahia and Espírito Santo (Rocha et al., 1997; Menezes \& Rocha, 2013). This lizard was included in the national (ICMBio/MMA, 2018) and state (Fraga et al., 2019) lists of fauna threatened with extinction, being categorized as Endangered in both lists, due to its restricted distribution and the intense degradation of the habitats in which this species is endemic (Colli et al., 2018; Almeida et al., 2007). The natural grassland (locally called "campo nativo") in the VNR is the type locality of this lizard and a recent study showed that the area maintains the highest density ever recorded for the species (Pereira-Ribeiro et al., 2020c), reinforcing the important role of VNR in maintaining the population and conserving this endangered species.

The reptile richness currently registered for VNR corresponds to about $5 \%$ of the known reptile species in Brazil and $13 \%$ of the known reptile species recorded for the Atlantic Forest (Tozetti et al., 2017; Costa \& Bérnils, 2018). In addition, the local species richness corresponds to about $30 \%$ of the species currently registered in the state of Espírito Santo (Costa \& Bérnils, 2018). Approximately $25 \%$ of the species we recorded in VNR are endemic to the Atlantic Forest biome (Tozetti et al., 2017) and four species are currently in some category of risk of extinction. However, part of the species that we found in the study (15\%) do not present information on their conservation status (IUCN, 2020). Thus, additional studies on reptile richness and composition are essential for the learning of occurrence, distribution, and status of conservation, which in turn, may provide more effective tools for the conservation of species, since occurrence and distribution data constitute essential components to assess the risk of extinction (IUCN, 2020).

We concluded that VNR contains many species of amphibians and reptiles, with a high number of endemic species of the Atlantic Forest, including some endangered species. Our study added four species to the known local herpetofauna biodiversity. The present species sampling provided the most current approximation of known the richness of the existing herpetofauna at VNR, since the period of the gathering of records is quite recent (2015-2018). Also, it brings the knowledge of some community parameters as species richness not only for the whole area of the VNR, but also for its different vegetation types, with no inclusion of environments outside this reserve. Our data reinforces the role of VNR as an important area for the protection of amphibian and reptile biodiversity in the Atlantic Forest.

AUTHORS' CONTRIBUTIONS: CFDR: Supervision; HGB, CFDR: Funding acquisition; JPR, ÁCF, HGB, CFDR: Conceptualization, Visualization, Investigation, Writing review \& editing; JPR, ÁCF: Methodology; JPR: Software, Data curation, Formal analysis, Writing - original draft. All authors actively participated in the discussion of the results, they reviewed and approved the final version of the paper.

CONFLICTS OF INTEREST: Authors declare there are no conflicts of interest.

FUNDING INFORMATION: This study is part of the results of the "Programa de Pesquisas em Biodiversidade da Mata Atlântica (PPBio Atlantic Forest Network)" of Ministério de Ciência, Tecnologia, Inovação e Comunicação (MCTIC) and was supported by Conselho Nacional de Desenvolvimento Científico e Tecnológico (CNPq) (Process No. 457458/2012-7) to HGB. The authors benefitted from grants provided to HGB (Process No. 307781/2014-3; 306585/2018-9) and to CFDR (Process No. 302974/2015-6; 424473/2016-0) from CNPq and through the Cientistas do Nosso Estado program from Fundação de Amparo à Pesquisa do Estado do Rio de Janeiro (FAPERJ) to CFDR (Process No. E-26/202.920.2015; E-26/202.803.2018) and to HGB (Process No. E-26/201.267.2014; E-26/202.757.2017). JPR received fellowships from FAPERJ (Process No. 247711 of E-26/201.756.2019 and 267724 of Programa PósDoutorado NOTA 10-2021 "PDR102021"). ÁCF received fellowships from FAPERJ (Process No. 240022 of E-26/202.198.2018 and 255804 of Programa PósDoutorado NOTA 10-2020 "PDR102020"). This study was financed in part by the Coordenação de Aperfeiçoamento de Pessoal de Nível Superior - Brasil (CAPES) - Finance Code 001.

ACKNOWLEDGMENTS: We thank Thiago Marcial de Castro and João Luiz Gasparini for their assistance in identifying the species during the study period, and Jane C.F. Oliveira for the photo of Erythrolamprus miliaris. The ICMBio provided the permit for the development of the study (No. 46327-4) and the Vale Natural Reserve for the support in the research.

\section{REFERENCES}

Almeida, A.P. \& Gasparini, J.L.R. 2014. Anfíbios na Reserva Natural Vale, Linhares, Espírito Santo, Brasil. Ciência \& Ambiente, 49: 211-218.

Almeida, A.P.; Gasparini, J.L. \& Peloso, P.L.V. 2011. Frogs of the state of Espírito Santo, southeastern Brazil - the need for looking at the 'coldspots.' Check List, 7: 542-460. 
Almeida, A.P.; Gasparini, J.L.; Abe, A.S.; Argolo, A.J.S.; Baptistotte, C.; Fernandes, R.; Rocha, C.F.D. \& Van-Sluys, M. 2007. 0s Répteis Ameaçados de Extinção no Estado do Espírito Santo. In: Passamani, M. \& Mendes, S.L. (Eds.). Livro de espécies ameaçadas de extinção no Espírito Santo. Vitória, IPEMA. p. 65-72.

Bergallo, H.G. \& Rocha, C.F.D. 1994. Spatial and trophic niche differentiation in two sympatric lizards (Tropiduridus Torquatus and Cnemidophorus ocellifer) with different foraging tatics. Austral Ecology, 19: 72-75.

Bérnils, R.S.; Almeida, A.D.P.; Gasparini, J.L.; Srbek-Araujo, A.C.; Rocha, C.F.D. \& Rodrigues, M.T. 2014. Répteis na Reserva Natural Vale, Linhares, Espírito Santo, Brasil. Ciência e Ambiente, 49: 193-210.

Campos, F.S. \& Lourenço-de-Moraes, R. 2017. Anurans from the mountain chain Serra do Mar: a critical area for amphibian conservation in the Atlantic Forest, Brazil. Herpetology Notes, 10: 547-560.

Chiarello, A.; Srbek-Araujo, A.; Del-Duque-Jr., H.; de Coelho, E. \& Rocha, C. 2010. Abundance of tegu lizards (Tupinambis merianae) in a remnant of the Brazilian Atlantic forest. Amphibia-Reptilia, 31: 563-570.

Colli, G.R.; Fenker, J.A.; Tedeschi, L.G.; Bataus, Y.S.L.; Uhlig, V.M.; Lima, A.S.; Nogueira, C.C.; Borges-Nojosa, D.M.; Costa, G.C.; Moura G.J.B.; Winck, G.R.; Silva, J.R.S.; Vinas, L.V.; Ribeiro Júnior, M.A.; Hoogmoed, M.S.; Tinoco, M.S.; Santos, P.A.; Valadão, R.M.; Oliveira, R.B.; Pires, T.C.S.A.; Ferreira, V.L. \& Menezes, V.M. 2018. Ameivula nativo. In: Instituto Chico Mendes de Conservação da Biodiversidade (Org.). Livro Vermelho da Fauna Brasileira Ameaçada de Extinção: Volume IV - Répteis. Brasília, ICMBio. p. 115-117.

Colombo, A.F. \& Joly, C.A. 2010. Brazilian Atlantic Forest lato sensu: the most ancient Brazilian forest, and a biodiversity hotspot, is highly threatened by climate change. Brazilian Journal of Biology, 70(3), Suppl. S1: 697-708.

Colwell, R.K. 2013. EstimateS, Version 9.1: Statistical estimation of species richness and shared species from samples. Software and User's Guide). Freeware published at http://viceroy.eeb.uconn.edu/estimates.

Costa, H.C. \& Bérnils, R.S. 2018. Répteis do Brasil e suas unidades federativas: lista de espécies. Herpetologia Brasileira, 7: 11-57.

Crump, M.L. \& Scott-Jr., N.J. 1994. Visual encounter surveys. In: Heyer, W.R.; Donnelly, R.W.; McDiarmid, M.A.; Hayek, L.A.C. \& Foster, M.S. (Eds.). Measuring and monitoring biological diversity: Standard methods for amphibians. Washington DC, Smithsonian Institution Press. p. 84-92.

Dias, I.R.; Medeiros, T.T.; Nova, M.F.V. \& Solé, M. 2014. Amphibians of Serra Bonita, southern Bahia: a new hotpoint within Brazil's Atlantic Forest hotspot. ZooKeys, 449: 105-130.

Ferreguetti, Á.C.; Pereira-Ribeiro, J.; Bergallo, H.G. \& Rocha, C.F.D. 2018. Abundance, density and activity of Salvator merianae (Reptilia: Teiidae) and the effect of poaching on the site occupancy by the lizard in an Atlantic Forest Reserve, Brazil. Austral Ecology, 43(6): 663-671.

Filogônio, R.; Assis, V.B.; Passos, L.F. \& Coutinho, M.E. 2010. Distribution of broadsnouted caiman (Caiman latirostris, Daudin 1802, Alligatoridae) in the São Francisco River basin, Brazil. Brazilian Journal of Biology, 70(4): 961-968.

Fraga, C.N.; Formigoni, M.H. \& Chaves, F.G. 2019. Fauna e flora ameaçadas de extinção no estado do Espírito Santo. Santa Teresa, ES, Instituto Nacional da Mata Atlântica.

Frost, D.R. 2019. Amphibian Species of the World: an Online Reference. Version 6.0. American Museum of Natural History, New York. http:// research.amnh.org/vz/herpetology/amphibia/index.php.

Gandolfi, S.M. \& Rocha, C.F.D. 1998. Orientation of thermoregulating Tropidurus torquatus (Sauria: Tropiduridae) on termite mounds. Amphibia-Reptilia, 19: 319-323.

Garay, I. \& Rizzini, M.C. 2004. A Floresta Atlântica de Tabuleiros: diversidade funcional da cobertura arbórea. Petrópolis, Editora Vozes.

Gasparini, J.L. 2012. Anfibios e répteis de Vitória e Grande Vitória, Espírito Santo. Vitória, Gráfica e Editora GSA.
Giaretta, A.A. 1996. Tropidurus torquatus: Home Range. Herpetological Review, 27: 80-81.

Haddad, C.F.B.; Toledo, L.F.; Prado, C.P.A.; Loebmann, D.; Gasparini, J.L. \& Sazima, I. 2013. Guia dos anfíbios da Mata Atlântica: diversidade e biologia. São Paulo, Anolis Books.

Hutchens, S.J. \& DePerno, C.S. 2009. Efficacy of sampling techniques for determining species richness estimates of reptiles and amphibians. Wildlife Biology, 15: 113-122.

Instituto Chico Mendes de Conservação da Biodiversidade/Ministério do Meio Ambiente (ICMBio/MMA). 2018. Livro Vermelho da Fauna Brasileira Ameaçada de Extinção. Brasília, ICMBio.

International Union for Conservation of Nature and Natural Resources (IUCN). 2020. The IUCN Red List of Threatened Species. http://www.iucnredlist. org.

Iverson, J.B. 1992. A revised checklist with distribution maps of the Turtles of the world. Richmond, Indiana, J.B. Iverson.

Jerozolimski, A.; Ribeiro, M.B.N. \& Martins, M. 2009. Are tortoises important seed dispersers in Amazonian forests? Oecologia, 161(3): 517-528.

Kierulff, M.C.M.; Avelar, L.H.S.; Ferreira, M.E.S.; Povoa, K.F. \& Bérnils, R.S. 2014. Reserva Natural Vale: História e aspectos físicos. Ciência \& Ambiente, 49: 7-35.

Loyola, R.D.; Kubota U. \& Lewinsohn, T.M. 2007. Endemic vertebrates are the most effective surrogates for identifying conservation priorities among Brazilian ecoregions. Diversity and Distributions, 13(4): 389-396.

Magnusson, W.E.; Lima, A.P.; Luizão, R.; Luizão, F.; Costa, F.R.C.; Castilho, C.V. \& Kinupp, E.V.F. 2005. RAPELD: A modification of the gentry method for biodiversity surveys in long-term ecological research sites. Biota Neotropica, 5: 1-6.

Magurran, A.E. 2013. Measuring biological diversity. John Wiley \& Sons, Malden, MA.

Marques, 0.A.V.; Eterovic, A. \& Sazima, I. 2019. Serpentes da Mata Atlântica: guia ilustrado para as florestas costeiras do Brasil. São Paulo, Editora Ponto A.

Menezes, V.A. \& Rocha, C.F.D. 2013. Geographic distribution, population densities, and issues on conservation of whiptail lizards in restinga habitats along the eastern coast of Brazil. North-Western Journal of Zoology, 9(2): 337-344.

Merçon, L. 2015. Últimos refúgios: Reserva de Biológica de Sooretama. Vitória, Instituto Últimos Refúgios.

Monteiro-Filho, E.L.D.A. \& Conte, C.E. 2017. Revisões em Zoologia: Mata Atlântica. Curitiba, Editora UFPR.

Moulton, T.P.; Magnusson, W.E. \& Melo, M.T.Q. 1999. Growth of Caiman latirostris inhabiting a coastal environment at Ilha do Cardoso, SP, Brazil. Journal of Herpetology, 33(3): 479-484.

Myers, N.; Mittermeier, R.A.; Mittermeier, C.G.; Da Fonseca, G.A. \& Kent, J. 2000. Biodiversity hotspots for conservation priorities. Nature, 403(6772): 853-858.

Oliveira, J.C.; Winck, G.R.; Pereira-Ribeiro, J. \& Rocha, C.F.D. 2016. Antropogenic effect or niche preference? Contributions to the knowledge of Hemidactylus mabouia invasion in South America. North-Western Journal of Zoology, 12(2): 389-392.

Peixoto, A.L.; Silva, I.M.; Pereira, 0.J.; Simonelli, M.; Jesus, R.M. \& Rolim, S.G. 2008. Tabuleiro forests north of the Rio Doce: their representation in the Vale do Rio Doce natural reserve, Espírito Santo, Brazil. In: Thomas, W.W. (Ed.). The Atlantic coastal Forest of Northeastern Brazil. Bronx, The New York Botanical Garden. p. 313-348. (Memoirs of the New York Botanical Garden, New York, n. 100).

Pereira-Ribeiro, J.; Ferreguetti, A.C.; Bergallo, H.G. \& Rocha, C.F.D. 2019. Good timing: evaluating anuran activity and detectability patterns in the Brazilian Atlantic Forest. Wildlife Research, 46(7): 566-572. 
Pereira-Ribeiro, J.; Ferreguetti, A.C.; Bergallo, H.G. \& \& Rocha, C.F.D. 2020a. Changes in the community structure of anurans in the Coastal plain forest, southeastern Brazil. Ecological Research, 35(3): 540-549.

Pereira-Ribeiro, J.; Ferreguetti, A.C.; Bergallo, H.G. \& Rocha, C.F.D. 2020 b. It's raining today! The importance of fine-scale rainfall data to reveal abundance patterns of Brazilian Atlantic Forest frogs. Herpetology Notes, 13: $245-248$.

Pereira-Ribeiro, J.; Ferreguetti, A.C.; Bergallo, H.G. \& Rocha, C.F.D. 2020c. Density, population size, and habitat use by Ameivula nativo (Teiidae) in a Remnant of Atlantic Forest in Brazil. Herpetological Conservation and Biology, 15(3): 558-566.

Pritchard, P.C.H. \& Trebbau, P. 1984. The Turtles of Venezuela. Athens, Ohio, Society for the Study of Amphibians and Reptiles.

Rezende, C.L.; Scarano, F.R.; Assad, E.D.; Joly, C.A.; Metzger, J.P.; Strassburg, B.B.N.; Tabarelli, M.; Fonseca, G.A. \& Mittermeier, R.A. 2018. From hotspot to hopespot: An opportunity for the Brazilian Atlantic Forest. Perspectives in ecology and conservation, 16: 208-214.

Ribeiro, M.C.; Metzger, J.P.; Martensen, A.C.; Ponzoni, F.J. \& Hirota, M.M. 2009. The Brazilian Atlantic Forest: How much is left, and how is the remaining forest distributed? Implications for conservation. Biological conservation, 142(6): 1141-1153.

Rocha, C.F.D. 1998. Composição e organização da comunidade de répteis da área de Mata Atlântica da região de Linhares, Espírito Santo. In: Seminário Regional de Ecologia, 8 . Anais. São Carlos, SP, Universidade Federal de São Carlos. v. 2, p. 869-881.

Rocha, C.F.D. \& Vrcibradic, D. 1998. Reptiles as predators and as preys in a restinga habitat of Southeastern Brazil. Ciência \& Cultura, 50(5): 364-368.

Rocha, C.F.D.; Anjos, L.A. \& Bergallo, H.G. 2011. Conquering Brazil: the invasion by the exotic gekkonid lizard Hemidactylus mabouia (Squamata) in Brazilian natural environments. Zoologia, 28(6): 747-754.

Rocha, C.F.D.; Bergallo, H.G.\&Peccinini-Seale, D. 1997. Evidence of an unisexual population of the Brazilian whiptail lizard genus (nemidophorus (Teiidae), with description of a new species. Herpetologica, 53(3): 374-352.
Rocha, C.F.D.; Bergallo, H.G.; Pombal-Jr., J.P.; Geise, L.; Van-Sluys, M.; Fernandes, R. \& Caramaschi, U. 2004. Fauna de anfíbios, répteis e mamíferos do Estado do Rio de Janeiro, sudeste do Brasil. Publicações Avulsas do Museu Nacional, 10: 3-23.

Rolim, S.G.; Menezes, L.D. \& Srbek-Araujo, A.C. 2016. Floresta Atlântica de Tabuleiro: diversidade e endemismos na Reserva Natural Vale. Belo Horizonte, Editora Rona.

Rossa-Feres, D.C.; Garey M.V, Caramaschi U.; Napoli M.F.; Nomura F.; Bispo A.A.; Brasileiro C.A.; Thomé M.T.C.; Sawaya R.J.; Conte C.E.; Cruz, C.A.G.; Nascimento, L.B.; Gasparini, J.L.; Almeida, A.P. \& Haddad, C.F.B. 2017. Anfíbios da Mata Atlântica: lista de espécies, histórico dos estudos, biologia e conservação. In: Monteiro-Filho, E.L.A. \& Conte, C.E. (Orgs.). Revisões em zoologia: Mata Atlântica. Curitiba, Editora Universidade Federal do Paraná. p. 237-314.

Scott-Jr., N.J.; Aquino, A. \& Fitzgerald, L.A. 1990. Distribution, habitats and conservation of the caiman (Alligatoridae) of Paraguay. Vida Silvestre Neotropical, 2: 43-51.

Siroski, P.; Bassetti, L.A.B.; Piña, C. \& Larriera, A. 2020. Caiman latirostris. The IUCN Red List of Threatened Species 2020: e.T46585A3009813. Download: 10/12/2020.

Tortoise \& Freshwater Turtle Specialist Group. 1996a. Acanthochelys radiolata (errata version published in 2016). The IUCN Red List of Threatened Species 1996: e.T78A97260100. https://doi.org/10.2305/IUCN.UK.1996. RLTS.T78A13078282.en. Download: 30/11/2020.

Tortoise \& Freshwater Turtle Specialist Group. 1996b. Chelonoidis denticulata. The IUCN Red List of Threatened Species 1996: e.T9008A12949796. https://doi.org/10.2305/IUCN.UK.1996.RLTS.T9008A12949796.en. Download: 30/11/2020.

Tozetti, A.M.; Sawaya, R.J.; Molina, F.B.; Bérnils, R.S.; Barbo, F.E.; Leite, J.C.M.; Borges-Martins, M.; Recoder, R.; Junior, M.T.; Argôlo, A.J.S.; Morato, S.A.A. \& Rodrigues, M.T. 2017. Répteis. In: Monteiro-Filho, E.L.A. \& Conte, C.E. (Orgs.). Revisões em zoologia: Mata Atlântica. Curitiba, Editora UFPR. 490p.

\section{APPENDIX}

Voucher specimens of taxa recorded during field samplings in Vale Natural Reserve, Espírito Santo, Brazil, in the period of June 2015 to February 2018. Specimens with field numeration (RNV) will be deposited later at the herpetological collection of the National Atlantic Forest Institute (INMA: Instituto Nacional da Mata Atlântica), in Santa Teresa, Espírito Santo state and Museu Nacional, Universidade Federal do Rio de Janeiro (MNRJ).

Amphibians: Aparasphenodon brunoi (MNRJ 91008, 91009, 91010), Boana pombali (RNV 140), Chiasmocleis schurbarti (MNRJ 91213, 91214, 91215), Dasypops schirchi (RNV 126), Densopsophus bipunctatus (RNV 114, 115), Dendropsophus decipiens (MNRJ 91224), Dendropsophus minutus (RNV 125), Haddadus binotatus (RNV 110, 118, 120), Ololygon agilis (MNRJ 91228), Ololygon argyreornata (MNRJ 91225, 91226), Physalaemus aguirrei (RNV 117), Physalaemus gr. signifer (MNRJ 91217, 91218), Proceratophrys laticeps (RNV 127, 128), Rhinella crucifer (RNV 113), Rhinella granulosa (RNV 119) Scinax alter (MNRJ 91222, 91223), Scinax euridyce (MNRJ 91221), Scinax sp. (MNRJ 91220), Stereocyclops incrassatus (RNV 141).

Reptiles: Amerotyphlops brongersmianus (RNV 52, 59, 60), Amphisbaena alba (RNV 123), Chironius foveatus (RNV 73), Drymoluber dichrous (RNV 144), Ecpleopus gaudichaudii (RNV 62), Gymnodactylus darwinii (RNV 40), Kentropix calcarata (RNV 142), Leposoma scincoides (MNRJ 26375), Micrablepharus maximiliani (RNV 131, 132), Norops ortonii (RNV 72), Brasiliscincus agilis (RNV 129), Strobilurus torquatus (RNV 55), Tantilla sp. (MNRJ 26376). 